\title{
GREEKS, BARBARIANS AND STRANGERS IN PAPYROLOGICAL FRAGMENTS OF LOST NOVELS*
}

\author{
MARÍA PAZ LÓPEZ MARTÍNEZ \\ University of Alicante \\ For Emilio, $\delta \imath \delta \alpha c \kappa o ́ \lambda \lambda \omega \imath ~ \phi \imath \lambda o c o \phi i ́ \alpha c$
}

\begin{abstract}
Una de las cuestiones que ha despertado reciente interés entre los helenistas es la postura que los griegos adoptaron hacia los otros pueblos antiguos con los que mantuvieron contacto, en una actitud oscilante entre la presunción y la curiosidad. Nuestro propósito es ilustrar el tema en el marco concreto de los fragmentos de novela, intentando alcanzar alguna hipótesis de carácter más general.
\end{abstract}

One of the question which has aroused great interest amongs Hellenists over the last decades, surrounding which there is extensive bibliography, is the Greeks' attitude to other peoples they termed barbarians. Even though we risk simplifying we could sum up by stating that the Greeks.

Our aim here is to illustrate this contradiction within the specific framework of papyrological fragments which could have belonged to novels now lost to us ${ }^{1}$, and by this short study arrive at some general conclusion².

First, we will refer to texts which, directly or indirectly, defend the Greek character. To follow we will look at fragments, which have as their main characters members of those barbarian nations the Greeks kept such close ties with over the centuries. For that very reason they were so familiar to them: Phoenicians, Egyptians, Persians, Syrians, Babylonians, Scythians, Arabs, Ethiopians... The desire to learn about them usually follows one of two trends: apparent objectivity or a tendency towards xenophobia ${ }^{3}$.

However, this is not the end of the matter. Greeks and barbarians both lived in the same world of the "known", so the coordinates of the stories included in the above mentioned groups are life-like, or even at times, taken from reality. We are referring in particular here to the historical novel. Beyond these limits lies an unknown universe, governed by completely imaginary laws. This is the world of the texts we include in the last section.

I. Metiochos and Parthenope (PBerol 9588, PBerol. 7927, PBerol. 21179, POxy. 435?; OBodl. 2175) (Lavagnini 1922, 21-24 and 28-29; Zimmermann 1936, $\mathrm{n}^{\circ} 6 \mathrm{~A}, 6 \mathrm{~B}$ and 6C, 52-63; Stephens and Winkler 1995, 72-100; López Martínez 1998b, 121-144): We shall start with some fragments which recreate an atmosphere akin to Chariton's historical novel (Hägg, 1987, 184-204). Parthenope (Ziegler, RE, 18.4.1935-36), the daughter of the famous tyrant Polykrates of Samos, is the heroine of a novel in which the male protagonist is another character from the history of Greece. Parthenope's partner was Metiochos (Fabricius, 'Metiochos', RE, 15.2.1407-1408), son in turn of the victorious hero at the battle of Marathon. The plot takes place in a context which is relatively near in time and space for the

\footnotetext{
* Our thanks to Professor A. Bernabé, Universidad Complutense and to Professor B.P. Reardon, UC Irvine, who have read this article and who are not responsible for any errors that remain.

${ }^{1}$ These fragments have been catalogued as novels in a way which may appear somewhat provisional. We have opted to apply an all-embracing criterion, even at the risk of offering, at times, more suggestions than conclusions, awaiting respondeant meliores et doctiores. The catalogue we propose appeared in López Martínez, 1997, 636-642.

${ }^{2}$ Here we are exclusively concerned with the panorama the fragments offer, and how the non-Greek influenced the complete novels, and regarding the Greek/Barbarian antithesis itself, from a global viewpoint, we recommend Bibliography-Appendix A.

${ }^{3}$ On the themes of nationalism and the antithesis of the barbarian and the Greek, please refer to the Bibliography-Apperidix B.
} 
intended reader (Herodotus 3.124; 3.140-51; 6.39-4I). The type of episode narrated in the novel threw a rosy light on the role of the Greeks in history. However, we cannot presume that the same applies to the other peoples who supposedly took part in the events, for it is a well-known historical fact that Polykrates of Samos was executed by the Persian satrap Oroetes, and, according to a very plausible reconstruction of the story (Hägg, 1984, 61-92), young Parthenope was abducted by the king of Persia and was thus the victim of another vile act.

PHarris 173 (López Martínez 1998b, 337340): The classification as novel of this papyrus can not be ensured due to its poor condition. The little left to us would lead us to believe it to be linked to the work of Pseudo-Callisthenes, as in the first chapter of this fictional biography we are told that Alexander is educated by Greek

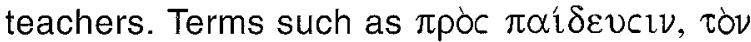

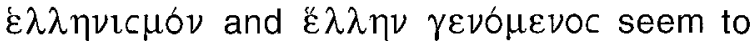
refer to the peculiarities of the Greek character.

II. Kalligone (PSI 981; POxy. ined. 112/ $130 \mathrm{a}^{4}$ ) (Zimmermann 1936, $N^{\circ}$ 4, 46-50; Stephens and Winkler 1995, 267-276; López Martínez 1998b, 145-155): At other times we clearly see evidence of Greek chauvinism in the papyri. Kalligone's name which speaks for itself and her strong personality lead us to assume that she must have been the heroine of the lost novel which the fragment bearing the same name probably belonged to. We have tried to reconstruct the storyline of the novel by comparing it to one of Lucian's works entitled Toxaris. Judging from this, Kalligone was abducted by the Scythians and in a fit of rage she gives a speech in favour of her Greek identity. The character is in many ways similar to that of Euripides' Medea: both prove to have a very strong personality. There is even a suggestion that they are slightly mentally unbalanced. It turns out that they are also both foreigners, although paradoxically they are in opposite situations. Medea is a barbarian in Hellenic territory and Kalligone is a Greek in foreign lands.

POxy. 417 (Stephens and Winkler 1995, 438-443; López Martínez 1998b, 322-328): The Scythians could also be the ones who are responsable for the kidnapping of the small son of a woman called Theano, who asks the Gods to help her find his whereabouts.

PSI 726 (Lavagnini, 1922,29-30, Zimmermann, 1936, $n^{\circ} 9,78-84$; Stephens and Winkler
1995, 277-288; López Martínez 1998b, 296 306): In the papyrus entitled Antheia there is a possible reference to the Taurians ${ }^{5}$. These people were the former inhabitants of the Crimean peninsula. They were pirates in the Black Sea and became allies of the Scythian king at the end of the XIth century B.C.

$P S I 151$ and PMil Vogl. 260 (Lavagnini, 1922, 32-33; Zimmermann, 1936, $\mathrm{n}^{\circ}$ 5, 50-52; Stephens and Winkler 1995, 391-399; López Martínez 1998b, 329-336): Apollonius is the protagonist of some fragments in which the presence of satraps and magnates gathered together at a banquet held by the king fills the scene with the atmosphere of the Orient. Some scholars believe this to be the original from which the Latin novel Historia Apollonii Regis Tyri later derived. Possibly the oftquoted foreign adulteress also figured here (Chiarini, 1983, 267-292).

PBerol. inv. 11517 (Stephens and Winkler 1995, 375-388; López Martínez 1998b, 266-275): Alongside all these fragments and their propaganda, one text stands out. We cannot fully ensure that it is a member of the genre, although this would seem quite probable. The plot refers directly to the sacred in Greek civilization, the sanctuary at Delphi and the Pythia's oracle. To be highlighted is the fact that there is fierce criticism here of a cultural symbol so close to the heart of the Greeks that not even such a fine mind as Socrates himself was capable of ever questioning its existence. The criticism is charged with fine rationalist spirit. In the scene we see the priest of Delphi begging a bloodthirsty individual called Daulis for mercy. This character can be seen to be the leader of a foreign army, according to the first editor's conjecture, or else he could be the head of a paramilitary group of villains like the one described in Phoinikika by Lollianus ( $v$. infra). Daulis fires his accusations of mercenary behaviour in an expressive speech which is striking for how modern his line of argument sounds. He also dares to boast about his cruelty to the cowering prophet whom he is threatening to kill. The prophet implores his executioner not to commit the sacrilege of spilling his blood on

${ }^{4}$ Our thanks to Professor Parsons, Ashmolean Museum, Oxford for having pointed out the existence of an unpublished papyrus, which would correspond to the same novel, POxy. ined. 112/130 (a).

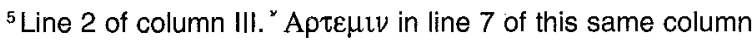
could back up this theory. Refer to Iphigenia Among the Taurians, by Euripides on this question. 
the god's altar. The sacrilegious nature of Daulis' character would be easier to justify if we could maintain that he is a foreigner who gets his just deserts for his impious behaviour. The name Daulis provides us with no information in this respect.

III. The next group to be discussed shows evidence of a great step forward as it includes several texts which grant the barbarians leading roles. In these fragments, the barbarians clearly play an important role right from the start. We are referring of course to figures like that of the Syrian king Ninus or the Egyptian leader Sesonchosis. Nevertheless, on studying these texts, we have to take into account another important factor: the heroes of these works may very possibly have actually existed. This fact makes them worthy of belonging to the subgenus, the historical novel, as was the case with Chariton's work or the fragments of Metiochos and Parthenope. However, if you compare how recent Chaireas and Kallirhoe or Metiochos and Parthenope are to the date their respective novels were written the barbarian protagonists are separated from their readers by a gaping abyss of time. This distance could be due to the fact that the main attraction these characters held in the story lies in their being leaders of great empires; an attraction no longer so strong at later dates ${ }^{6}$.

Ninus Romance (PBerol 6926, PGen. inv 85, PSI1305, OEdfou 306?) (Lavagnini, 1922, 1 15; Zimmermann 1936, $\mathrm{n}^{\circ}$ 1, 13-35; Kussl 1991, 13-101; Stephens and Winkler 1995, 23-71; López Martínez 1998b, 37-80): The vision of the historical past in the Ninus Romance gives the impression that it is objective. The figure of Ninus is well known in Greek tradition. He was the mythical founder of the city of Nineveh and the inventor of military skills. For the first time he got together great armies ${ }^{7}$.

Although the papyri have not passed down to us any special mention of the name of the heroine of the novel, we suppose that it was the Syrian queen, Sammu-ramat, who was of Babylonian origin and married to Shamshi-adad V -823-811 B.C-. This Assyrian king died when his son Adad-nirari III -810-783- was still a minor, for which reason Sammuramat took charge of the regency. Diodorus Siculus tells us that Semiramis was the illegitimate daughter of the Syrian goddess Derketo. She came to the aid of her husband Onnes, the king's adviser, at the expedition against Baktra, which is precisely where king Ninus met her (Diodorus Siculus 2.1-20).

The characters are portrayed in a domestic setting in one of the fragments. They are made to appear young, tender and loving in a way which appealed to people's taste during the Hellenistic and Imperial Ages, but this is far from the image reflected by other sources (Plutarchus, Erotikos $753 \mathrm{~d}-\mathrm{e}$. Others Greek sources: Herodotus, 1.184, 3.155; Hesychius, s.v.; Lucianus, De Syria dea D. 14 and Aelianus, Varia historia 7.1). The protagonists are two adolescents in love who follow the social conventions dictated by a cultural koinh/ which goes far beyond linguistic concerns. The young man is a soldier both brave and skilled at speech-making, whilst Semiramis is a young maiden as shy as she is chaste.

Sesonchosis' Romance (POxy. 1826, POxy. 2466, POxy. 3319) (Zimmermann 1936, 36-40, $n^{\circ} 2$; Stephens and Winkler 1995, 246266; López Martínez 1998b, 357-375): The same apparently objective picture is given of Senwosret I, the Egyptian pharaoh who lived around 1918 B.C. and inspired Sesonchosis' Romance. During his father's lifetime he was appointed co-ruler. He later reigned alone without too much going amiss. We know that during the Middle Empire literary texts were written in which reference is made to the role of Senwosret I and his father in the political events of that period. The latter are given a ficticious explanation.

Most Greek sources (Herodotus 2.102-11]; Diodorus Siculus 1.53-58; Pseudo-Callisthenes $1.33 .6 ; 3.17 .17 ; 3.24 .2 ; 3.34 .4$; Apollonius Rhodius 4.272. Kees, 'Sesonchosis' and 'Sesostris', RE, 2.A.2, 1855-1861 and 18611876) portray Sesonchosis as a great conqueror and statesman comparable to Alexander, but there already existed a literary tradition in Egypt which told of the exploits of this figure. Therefore

\footnotetext{
${ }^{6}$ The carliest possible date put forward for the writing of these novels -Novel of Ninus and Metiochos and Parthenope is the first century B.C. The historical characters Callirhoe or Parthenope, are from around the years 413-411 B.C. and 522 B.C., respectively. By comparison the real referents Ninus or Sesonchosis date from 1244-1208 B.C. -Ninus- and 1918-1875 B.C. -Sesonchosis-. Cf. Dihle, 1978, 47-55. A recent panoramic view of the development of the genre can be read in: Ruiz Montero, "The Rise of the Greek Novel" in Schmeling 1996, 29-85.
}

${ }^{7}$ We are studying the possibility that this legendary figure could have been inspired by the Assyrian king Tukulti-ninurta I who reigned from 1244 to 1208 and was, like the legendary Ninus, founder of a new capital: Kal Tukulti-ninurta. A poem was composed in his honour which is the only epic story which has come down to us from this ancient people. It tells of the war between Tukulti-ninurta and Kasthiliash IV of Babylon (12421235). 
we can say that Sesonchosis was probably the protagonist of a legend from time immemorial. In time, Senwosret I was also said to have taken part in events which did not take place until later during the reign of Senwosret III, and some people believe that the saga of Sesonchosis as conqueror of the world (which we find in Herodotus) dates from this period (West, 1980 , 11-12).

The novel probably told the story of how great pains were taken to educate Sesonchosis very well. Naturally, the study of military strategy was not overlooked. Sesonchosis' response to the Arabs' attack on Egyptian territory was to invade Arabia, and its king Webelis was brought down in status to vassal king. Sesonchosis probably showed himself to be magnanimous and kind-hearted by getting engaged to the daughter of Webelis. Thus the novel was guaranteed to have the couple's triumphal return to Egypt and a happy ending.

Indeed, we know from what Diodorus tells us that an Egyptian campaign against the Arabs did take place. It was in his father's lifetime when Sesonchosis was still a boy. However, as far as the name Webelis is concerned, the only thing we can say is that two Arabian kings are known called Wahbil. They lived at a much later date than the real Sesonchosis, in the years 310-290 B.C. and 180-160 BC. respectively. But nothing is known of any invasion of Egypt by the Arabs, either in general or specifically by a certain Webelis. Perhaps Egyptian national sentiment invented the prior provocation to justify their attack.

POxy. 3011(López Martínez 1998b, 341346): There is little evidence to back the hypothesis of the existence of a historical novel centred on the figure of Amenhotep III, the Egyptian pharaoh who reigned pacifically and prosperously around 1390-1353 B.C. Patron of gigantic buildings, he is known in Greek sources (Manetho Hist. FGrH 609 F 2; Pietschmann, 'Amenophis', RE, 1.2, 1824-1825) as Amenophis and Greek mythology identifies him with the famous Memnon. This ruler reigned over the Ethiopians and died in the Trojan war. One of the places he may be from is Thebes. Of the famous statues Amenhotep III erected one was called the Colossus of Memnon in his honour. The papyrus in question describes a road which probably led to Memphis and then the narrator asks someone he calls "brother" to behave like a man, and he carries him across the sea. The reading of 'A A 21-22).
Although the work of lamblichos has not come down to us in any papyrus, we believe it worthy of note that in the novel Babyloniaka (Habrich, 1960; Henry, 34-48 and Stephens and Winkler 1995, 179-245) the story takes place along the royal Persian road, as indicated by the title itself. The road follows the course of the river Euphrates where all kinds of dangers lie in wait in an atmosphere of uncertainty and confusion.

Phoinikika, Lollianus: PColon. inv. 3328, POxy. 1368 (Lavagnini 1922, 33; Stephens and Winkler 1995, 314-357; López Martínez 1998b, 163-208): The very subscriptio (fragment $A 2$ verso) preserved in the papyrus of Lollianus's work guarantees the Phoenicians an important role ${ }^{8}$. With this work we have to start a new chapter in our study. The author of Phoinikika crudely reflects the Greek's xenophobic tendencies ${ }^{9}$. For them anyone not Greek automatically personifies uncertainty and insecurity. We can assume what kind of heroes the novel had by looking at how they spent their time: deflowering, human sacrifice, orgies, masquerade, .... As the late Professor Winkler remarks in his study, such cruel pastimes are from the average Greek's point of view inconceivable for any civilized people like his own. Once again a real precedent could have served as the model for these savage criminals. Around the year 172 B.C. a group or shepherds, known as Boukó $\lambda$ or (Achilles Tatius 3.15; Cassius Dio 71.4; Sethe, 'Bovkód or 1', RE, 3.1, $1013)^{10}$, who lived in the Eastern part of the Nile Delta, led an uprising of which several Greek sources give an account. These gangs of conspirators, prompted more by antisocial feelings than by religious conviction, also inspired other Greek and Latin novelists (Apuleius' Metamorphoses, 4.22; PseudoLucianus," Ovoc 19).

PTurner 8 (Kussl 1991, 171-1172; Stephens and Winkler 1995, 400-408; López Martínez 1998b, 254-265) ${ }^{11}$ : Another papyrus

\footnotetext{
${ }^{8}$ On the question of the mention of the Orient in the novels: Treu $(1984,457)$ and Holzberg (1986, 46 and 103).

${ }^{9}$ Cf. Winkler (1980, 155-181).

${ }^{10}$ Schwartz (1967, 536-52); Liviabella (1985, 25-40) and Graf (1986, 43-44). Stephens and Winkler (1995, 320-321) do not favour associating the protagonists of the Phoinikika with Greek herdsmen.

${ }^{11}$ Interesting comparisons can be made with the text of this papyrus and those in different languages from different periods, such as Life of Achikar and Life of Aesop. During the 19th Groningen Colloquium on the Novel, I proposed that this corpus could be enlarged, taking into consideration one more reference point: the fragment called Dream of Nektanebos ( $v$. López Martínez 1998b, 21-36).
} 


\begin{tabular}{|c|c|c|c|}
\hline \multicolumn{3}{|c|}{ KNOWN: MEALILAUSIDLE } & \multirow{2}{*}{$\begin{array}{l}\text { UNKNOWN: MMAGINARY } \\
\text { IV. STRANGERS }\end{array}$} \\
\hline I. GREEKS & $\begin{array}{l}\text { II. GREEKS/ } \\
\text { BARBARIANS }\end{array}$ & $\begin{array}{l}\text { III. BARBA- } \\
\text { RIANS }\end{array}$ & \\
\hline $\begin{array}{lr}\text { Metiochus } & \text { and } \\
\text { Parthenope } & \text { P.Berol. } \\
9588, \quad P . B e r o l & 2927, \\
9 . \text { Berol. 21179, P.Oxy. } \\
\text { P.B5, O.Bodl. } 2175\end{array}$ & Kalligone(PSI 981) & \begin{tabular}{l}
\multicolumn{1}{c}{$(+)$} \\
Ninus Romance \\
P.Berol 6926; \\
P.Gen. inv 85, PSI \\
1305); O.Bodl. 306?
\end{tabular} & $\begin{array}{l}\text { Antonius Diogenes, The Incredible Things } \\
\text { beyond Thule (PSI 1177, P.Oxy. 3012) }\end{array}$ \\
\hline \multirow[t]{5}{*}{ PHarris 173} & Theano (P.Oxy. 417) & $\begin{array}{l}(+) \\
\text { Sesonchosis } \\
\text { (P.Oxy. Romance } 1826, \quad \text { P.Oxy. } \\
\text { 2466; P.Oxy. 3319) }\end{array}$ & \\
\hline & Antheia $(P S I 726)$ & $\begin{array}{l}(+) \\
\text { Amenophis } \quad(P . O x y . \\
3011) ?\end{array}$ & \\
\hline & $\begin{array}{l}P S I 151 \text { and P.Mil. Vogl. } \\
260\end{array}$ & $\begin{array}{l}\quad(\cdot) \\
\text { Lollianos'A Phoenician } \\
\text { Story } \\
\text { (P.Colon. inv. 3328, } \\
\text { P.Oxy. 1368) }\end{array}$ & \\
\hline & 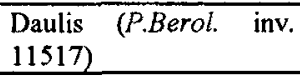 & $\begin{array}{c}(-) \\
\text { Tinouphis (P.Turner } 8)\end{array}$ & \\
\hline & & $\begin{array}{ll}\text { Nectabebo's } & \text { Dream } \\
(\text { P.Leid. U) } & \\
\end{array}$ & \\
\hline
\end{tabular}

which paints a none too flattering picture of foreigners is the one with the leading character Tinouphis. Examples are given here too of the cruelty which governs relationships between the barbarians. In this case the story appears to be set either in the territory of Prehellenistic Persia, or in Egypt at the time of the Persian invasion. An Egyptian prophet, who has been condemned to be entombed alive, finally manages to escape thanks to the shrewdness of the builder who has a Greek-sounding name, Sosias.

IV. All these texts have allowed us to travel around a world where the behaviour of Greeks and barbarians is determined by the limits of the plausible, governed by the same laws that govern reality. We have set forth from civilized lands which mean safety, and have gone farther afield to barbarian territory, to the north (Scythians, Taurians), the south (Egyptians, Ethiopians) and the east (Persians, Syrians, Babylonians, Phoenicians and Arabs). However, one last frontier remains to be crossed, a leap in the dark, into a realm where the writer is allowed to do almost as he likes (amongst recent studies on fiction and fictionality: Bowie, 1977; Tatum, 1989; Reardon 1991) 12 .

The Incredible Things beyond Thule, Antonius Diogenes: PSI 1177, POxy. 3012 (Zimmermann, 1936, 85-89 $n^{\circ}$ 10; Henry, 1960,
140-166; Reyhl, 1969; Fusillo, 1990; Kussl 1991, 173-175; Stephens and Winkler, 1995, 101172). Thus, the protagonists of the novel by Antonius Diogenes come in their wanderings right up to the edge of the known world, but they do not stop at the threshold, but, before returning home, cross it. What they find on the other side deserves to be described as $\alpha$ kic $\tau$ ov. To the far west of the Mediterranean live peoples whose customs are surprising: the inhabitants of one of the cities of Iberia can see at night, but become blind during the day, horses change colour on leaving the country, kings alternate power depending on the phases of the moon, and men stay at home doing the women's work whilst their women make war. The action goes on this time northwards to the northern-most tip of the world. The island of Thule is taken as the starting point of a route which leads to the North Pole and the moon itself. Naturally, the reader would have been interested in reading about all these adventures, because he would have been able to identify with the characters as they seemed believable. To strengthen the credibility Antonius Diogenes presents written proof: there is a manuscript to

${ }^{12}$ We think that the fictitious paradise of utopian novels such as the one by lambulus, could also fit into this category ( $v$. Holzberg and Kuch in Schmeling 1996, 621-628 and 216-217). 
back up the events of the novel. His story can be checked out ${ }^{13}$.

We would like to ask whether a text like that by Antonius Diogenes, could, in spite of everything, reflect a step back to the universe of myth, away from the rationality and realism aimed at in novels like the Ninus Romance, or the Phoinikika.

To conclude we would comment that the "superiority complex" of Greek nationalism is reflected, once more, in the small sphere of the papyrological fragments of the lost novels. The illustrious barbarian kings, like Ninus, Sesonchosis, and, possibly, Amenophis, are an exception. Their antiquity, considering the date of the novels in which they are principal characters, confers notable prestige on them. The respect in which the Greeks held the Egyptians in particular possibly helped to boost that prestige.

To aid clarity we have included all the papyrii referred to in a table here below. Where the barbarians play a leading role, the signs "+" and "-" indicate the positive or negative image reflected by the fragments.

\section{BIBLIOGRAPHY}

BOWIE, E. L. 1977: "The Novels and the Real World" in REARDON, 1977, 91-96.

CHIARINI, G. 1983: "Esogamia e incesto nella Historia Apollonii regis Tyri", MD, 10-11, 267-292.

DIHLE, A. 1978: "Zur Datierung des Metiochos-Romans" WJA, 4, 47-55

DOSTÁLOVÁ, R. 1991: / romanzo greco e i papiri, Prague (review by LAPLACE, M. M. J. 1993: REG, 106, 256259).

FUSILLO, M. (ed.). 1990: Antonio Diogene. Le incredibili avventure al di lá di Tule, Palermo.

GARIN, F. 1920: "I Papiri d'Egitto e i Romanzi Greci", SIFC, $1,163-181$

GRAF, F. 1986: "BOYKO OI", ZPE, 62, 43-44

HABRICH, E. (ed.). 1960: lamblichi Babyloniacorum Reliquiae, Leipzig.

HÄGG, T. 1984: «The Parthenope Romance Decapitated?», SO, 59, 61-92.

1987: "Callirhoe and Parthenope. The beginnings of the historical novel", ClAnt., 6, 184-204.

HENRY, R. (ed.). 1960: Photius, Bibliothéque, vol. 2, Paris, 34-48.

HOLZBERG, N. 1986: Der antike Roman: Eine Einführung, München.

KUSSL, R. 1991: Papyrusfragmente griechischer Romane. Ausgewählte Untersuchungen, Tübingen (Reviews of GRONEWALD, M. 1993: Göttingische Gelehrte Anzeige, 3/4, 187-200 and LAPLACE, M. M. J. 1995: REG 108, 256-264).

LAVAGNINI, B. 1922: Eroticorum Graecorum Fragmenta Papyracea, Leipzig.

LIVIABELLA, P. 1985: "Religione e letteratura nel 'racconto' di sacrifici umani presso y romanzieri greci d'amore",
Quaderni dell'stituto di filosofia della Facoltà di Magistero - Perugia, 3, 25-40.

LÓPEZ MARTÍNEZ, M.P. 1997: "The Greek Novel. A Case of 'Opera Aperta'. Suggestions for a Catalogue of Novel Fragments", in KRAMER, B., LUPPE, W., MAEHLER, $\mathrm{H}$. and POETHKE, G. (edd.), 21.International Congress of Papyrology in Berlin 1995, II vol., Stuttgart-Leipzig, 636-642.

1998a: "Las otras novelas griegas", in ADRADOS, F.R. and MARTíNEZ DÍEZ, A. (edd.), Actas del IX Congreso español de Estudios Clásicos, Madrid 1995, Madrid, 208212.

1998b: Fragmentos papiráceos de novela griega, Alicante (1994 on microfiche).

MAEHLER, H. 1983: "Fragmente aus Liebesromanen" in K. KYTZLER (ed.) Im Reiche des Eros. Samtliche Liebesund Abenteuerromane der Antike I/, München, 715-750.

MENDOZA TUÑ́́N, J. 1979: "Fragmentos novelescos", Caritón de Afrodisias, Quéreas y Calírroe. Jenofonte de Éfeso, Efesiacas, Fragmentos novelescos, Madrid, $317-$ 417.

PECCERE, O. and STRAMAGLIA, A. (edd.). 1996: La Letteratura di consumo nel mondo greco-latino. Atti del Convegno Internazionale. Cassino, 14-17 settembre 1994, Cassino.

RATTEMBURY, R. M. 1933: "Romance: Traces of Lost Greek Novels" in POWELL, J.U. (ed.), New Chapters in the History of the Greek Literature, Oxford, 211-257.

REARDON, B. P. (ed.), 1977: Erotica Antiqua: Acta of the International Conference on the Ancient Novel 1976, Bangor, Wales.

1991: The Form of Greek Romance, Princeton, 46-126.

REYHL, K. 1969: Antonius Diogenes: Untersuchungen zu den Roman-Fragmenten der 'Wunder jenseits von Thule' und $z u$ den 'Wahren Geschichten' des Lukian, Tübingen.

SANDY, G. N. 1989: in B. P. REARDON (ed.) Collected Ancient Greek Novels, Berkeley-Los Angeles, 801-827. 1994: "New Pages of Greek Fiction" in MORGAN, J. R. and STONEMAN, R. (edd.) Greek Fiction. The Greek Novel in Context, London-New York, 139-145.

SCHMELING, G. (ed.). 1996: The Novel in The Ancient World, Leiden-New York-Köln.

SCHWARTZ, J. 1967: "Quelques Observations sur des romans grecs", $A C, 36,536-52$.

STEPHENS, S. A. and WINKLER, J. J. 1995: Ancient Greek Novels. The Fragments. Introduction, Text, Translation, and Commentary, Princeton-New Jersey (Review by WOUTERS, A. 1996: EC, 64, 300-301 and LÓPEZ MARTÍNEZ, M. P. 1996: Tempus. Revista de actualización científica, 13, 73-77).

STEPHENS, S. A. 1996: "Fragments of Lost Novels" in SCHMELING, 1996, 655-683.

TATUM, J. 1989: Xenophon's Imperial Fiction, Princeton.

TREU, K. 1984: "Roman und Geschichtsschreibung", Klio, 66, 456-459

WEST, S. 1980: The Oxyrhynchus-Papyri, 47, 11-19.

WINKLER, J. J. 1980: «Lollianos and the Desperadoes», JHS, 100, 155-181.

ZIMMERMANN, F. 1936: Griechische Roman-Papyri und verwandte Texte, Heidelberg.

\footnotetext{
${ }^{13}$ There are authors who consider the possibility of classifying other papyri as Antonius Diogenes' fragments: PMich. inv. 5(Reyhl 1996, 14-20); PDubl. C3(Stephens and Winkler 1995, 158-172) and PGen. inv. 187(Kussl 1991, 173-175). We have not included the aforesaid papyri in this study because we entertain doubts about identifying them in this way, and, above all, because neither text is linked to the non-Greek context.
} 


\section{Àppendix Á}

BASLEZ, M.F., HOFFMANN Ph. and TRÉDÉ M. (edd.) 1992: Le monde du roman grec. Actes du colloque international tenu à l'École normale supérieure (Paris 17. 19 décembre 1987), Paris.

BASLEZ, M. F. 1992: "De l'histoire au roman: la Perse de Chariton", in BASLEZ, HOFFMANN and TRÉDÉ, 1992 , 199-212.

BONNEAU, D. 1992: "Les realia du paysage égyptien dans le roman grec: remarques lexicographiques" in BASLEZ, M.F., HOFFMANN Ph. and TRÉDÉ M. (edd.), 1992, 213219.

BRIQUEL-CHATONNET, F. 1992: 'L'image des Phéniciens dans les romans grecs" in BASLEZ, M.F., HOFFMANN Ph. and TRÉDÉ M. (edd.), 1992,189-197.

CAUDERLIER, P. 1992: "Réalités égyptiennes chez Héliodore", in BASLEZ, M.F., HOFFMANN Ph. and TRÉDÉ M. (edd.), 1992, 221-231.

CONCA, F., DE CARLI, E. and ZANETTO, G. 1983: Lessico dei Romanzieri Greci, I (A-G) Milan, 136, s.v. $\beta \not \alpha p \beta \alpha p o c$.

$\mathrm{KUCH}, \mathrm{H}$. 1989: "Die 'Barbaren' und der antike Roman", Das Altertum, 35, 80-86.

1996, "The Margin of the Ancient Novel."Barbarians" and Others" in SCHMELING, 1996, 209-220.

O'SULLIVAN, J. N. 1980: A Lexicon to Achilles Tatius, Berlin, 59.
PAPANIKOLȦOU, A. 1983: Index Xenophontis Ephesii, Athens, 18.

ROMM, J. S. 1992: The Edges of the Earth in Ancient Thought, Geography, Exploration, and Fiction, Princeton.

\section{Appendix B}

BARNS, J. W. B. 1978: Egyptians and Greeks, Bruxelles, 3-23

CARTLEDGE, P. 1993: The Greeks. A Portrait of Self and Others, Oxford - New York.

DIHLE, A. 1994, Die Griechen und die Fremden, München.

DILLER, H. 1962: "Die Hellenen-Barbaren-Antithese im Zeitalter der Perserkriege", in Grecs et Barbares. Entretiens sur l'Antiquité Classique 8, VandoeuvresGenève, 37-82.

LAUROT, A. 1981: "Idéaux Grecs et Barbarie chez Hérodote", Ktema, 6, 39-48.

LLOYD, A. B. 1982: "Nationalist Propaganda in Ptotemaic Egypt", Historia, 31, 33-55.

MACMULLEN, R. 1964: "Nationalism in Roman Egypt", Aegyptus, 44, 179-199.

NIPPEL, W. 1990: Griechen, Barbaren und "Wild", Frankfurt/ Mainz.

REVERDIN, O. 1962: "Crise Spirituelle et Évasion", in Grecs et Barbares. Entretiens sur l'Antiquité Classique 8 , Vandoeuvres-Genève, 83-120. 